Article

\title{
Bioactive, Physicochemical and Sensory Properties as Well as Microstructure of Organic Strawberry Powders Obtained by Various Drying Methods
}

\author{
Anna Sadowska *(D), Franciszek Świderski and Ewelina Hallmann \\ Department of Functional and Organic Food, Institute of Human Nutrition Sciences, Warsaw University of Life \\ Sciences, Nowoursynowska Str. 159c, 02-776 Warsaw, Poland; franciszek_swiderski@sggw.edu.pl (F.Ś.); \\ ewelina_hallmann@sggw.edu.pl (E.H.) \\ * Correspondence: anna_sadowska@sggw.edu.pl
}

Received: 16 June 2020; Accepted: 6 July 2020; Published: 8 July 2020

\begin{abstract}
This study compared the quality of organic strawberry powders, obtained by convective drying (CD), freeze drying (FD) and spray drying (SD) methods. In the study, such analyses were performed: the content of vitamin $C$ and polyphenols by liquid chromatography method, antioxidant activity using ABTS+ $\bullet$ radicals, microstructure using a scanning microscope, sensory quality by profile method and the determination of the physicochemical properties. The FD powders were characterised by the highest content of vitamin $C$ and polyphenols, obtained values were close to fresh strawberries after conversion to the dry matter content. The content of these ingredients in CD and SD powders was lower by $55 \%-80 \%$ for vitamin C, and $80 \%$ for the polyphenols content. Strawberry flavour was most beneficial for the FD powders, while smoothness and homogeneity of appearance were equally rated for the FD and SD powders. Strawberry powders are a concentrate source of bioactive compounds and, therefore, the FD powders should especially be mainly used as a valuable component of high-value foods, especially functional foods, while $\mathrm{CD}$ and SD powders can be used to enrich food with vitamin $C$ and as a valuable natural flavour and colouring component, replacing food additives.
\end{abstract}

Keywords: strawberry powders; drying; bioactive compounds; organic food

\section{Introduction}

Strawberries (Fragaria $x$ ananassa, D.), which belong to the Rosaceae family, are valued for their unique taste, intense red colour and juicy texture. They are classified as fruit with a high content of bioactive compounds with antioxidant, anti-inflammatory and anticancer effects. They are a source of vitamin $C$, the fruit containing $0.30-0.70 \mathrm{mg} \mathrm{g}^{-1}$, depending on the variety [1], so the consumption of a portion of about $200 \mathrm{~g}$ covers the need for this vitamin, which, according to the Regulation (EU) No 1169/2011 of the European Parliament and of the Council of 25 October 2011 on the provision of food information to consumers, is $80 \mathrm{mg}$ [2].

Strawberries are rich in phenolic compounds such as anthocyanins, ellagitannins, flavonols, flavanols and phenolic acids [3-6]. Literature data indicate that organic fruit, including strawberries, is usually characterised by a high content of bioactive ingredients $[7,8]$. Numerous studies indicate a beneficial prophylactic effect of strawberries on health [4,9-12]. Animal studies indicate the anticancer potential of freeze-dried strawberries and their dried extract in relation to oral cancer $[13,14]$. Strawberry extract shows antioxidant properties and antiproliferative activity, inhibiting the development of cancer cells in vitro [6]. The beneficial effect of freeze-dried strawberries was also demonstrated in studies carried out in patients with oesophageal dysplasia taking $60 \mathrm{~g} /$ day freeze-dried strawberries for six 
months [15]. In people with metabolic syndrome, a reduction in total cholesterol and LDL (low-density lipoprotein) cholesterol from taking $50 \mathrm{~g}$ of freeze-dried strawberry powder for 1 and 2 months has been documented [16,17].

Strawberries are seasonal, perishable, very susceptible to mechanical damage and easily spoiled. It is important to use appropriate technological operations to process them quickly after harvesting. They are frozen or processed into various types of intermediate products or preparations. Drying processes are one of the important groups of the processing methods. Dried fruit can be used in the production of a large group of food products, such as food concentrates, desserts, fruit teas, conditioners and dietary supplements. The spray drying and convective drying methods are most often used to obtain dried products, and in recent years, the freeze-drying method has become increasingly common. The dried product is obtained from juices (less often purees) using high carrier additives (maltodextrin), the quantity of the latter usually being $60 \%$ with respect to the juice [18]. Convective drying is widely used because of its low cost [19]. However, this method requires a long time, which causes significant degradation of bioactive components [20] and a colour change [21]. Another disadvantage of this method is the change in the structure of the products, due to shrinkage processes that result from changes in volume and lower humidity [22]. Sublimation drying is used to obtain dehydrated fruit and vegetables of high quality and high nutritional value, but this is an expensive and slow dehydration process $[23,24]$. Nevertheless, freeze-dried products are characterised by high quality and lifetime, which is related to the low temperature of the process, which runs without air, reducing oxidation reactions $[25,26]$. The advantage of sublimation drying is that the physical, chemical and biological properties of the raw materials are significantly preserved. The freeze-drying process is considered to cause the least loss of bioactive compounds and their antioxidant properties [25-29]. Some authors report, however, that the freeze-drying process may cause a significant reduction in the content of bioactive compounds, depending on the applied process and its conditions [6,30-32].

The available literature lacks data on the comparative analysis of the bioactive compound content and the sensory quality of strawberry powders, from both organic and conventional farms, obtained by freeze drying and convective drying methods with powders obtained by the widely used spray drying of strawberry juice. Our recent studies of fruit powders obtained from chokeberry and blackcurrant by the abovementioned methods, and additionally with the use of an innovative method of drying with simultaneous drying and grinding [33,34], showed a large variation in functional properties, bioactive ingredient content and sensory quality, depending on the method used to obtain the powders. Chokeberry and blackcurrant are among those fruits with a firm and compact texture, as opposed to berries such as strawberries-fruits with a soft, easily disintegrating texture and a much higher water content $[4,35,36]$.

The aim of this study was to examine and compare the quality characteristics of the different powders obtained from organic strawberries, which belong to the group of berries, providing valuable bioactive ingredients with health-promoting properties, and classified as so-called 'superfruits.' The available literature does not contain data on the characteristics of the powders obtained from organic strawberries using various drying methods. Comparison of the content of bioactive ingredients and the sensory quality of powders obtained using different drying methods is important from both the scientific and the commercial point of view. The results of this comparison may be a valuable guideline for manufacturers to decide on the use of powders depending on their quality, i.e., in the case of powders with a high content of bioactive ingredients, their use as dietary supplements or high quality food, while in the case of those with a lower content of active compounds, their use as natural additives increasing the sensory quality, especially the taste and colour of the products. Also, the functional properties, especially the solubility and textural characteristics and the associated microstructure of the powders, are very important in determining and selecting their applicability. 


\section{Materials and Methods}

\subsection{Materials}

The strawberries used for all the drying methods were of the same origin 'Honeoye.' Plants were cultivated using organic systems in a farm located in the Lublin region. The freeze-drying process was carried by using an Alpha 1-4 LSC lyophiliser (Martin Christ GmbH, Osterode am Harz, Germany) (initially frozen at $-30^{\circ} \mathrm{C}$ over a time of $48 \mathrm{~h}$, process pressure $10 \mathrm{~Pa}$, temperature in the drying chamber $-50{ }^{\circ} \mathrm{C}$, shelf temperature $21^{\circ} \mathrm{C}$ and processing time $48 \mathrm{~h}$ ). Convective drying was performed using an SUP-200G laboratory dryer with air circulation (Wamed Company, Warsaw, Poland) (air temperature $70{ }^{\circ} \mathrm{C}$, time $25 \mathrm{~h}$ ) to $\mathrm{a}_{\mathrm{w}}<0.3$. After the convective or freeze-drying processes, the dried material was ground to a powder using a grinder with grinding knives (MKM 6003, Bosch, Stuttgart, Germany) to give a granulation below $400 \mu \mathrm{m}$. The spray dried powders were obtained from strawberry juice with the addition of a $60 \%$ maltodextrin carrier (dextrose equivalent of DE 12) at air temperatures of $160{ }^{\circ} \mathrm{C}$ for the inlets and $90^{\circ} \mathrm{C}$ for the outlets, and with a $0.7 \mathrm{~mm}$ diameter dispersing nozzle being used (B-290, Mini Spray Dryer, Büchi, Flawil, Switzerland). Powders in a size range between 630 and $315 \mu \mathrm{m}$ were selected for analysis. Particle classification of powders was performed with the use of a vibratory sieve shaker (AS 200, RETSCH GmbH \& Co., Haan, Germany).

\subsection{Methods}

The antioxidant activity in water extracts of the test material was determined by the ABTS+ $\bullet$ (2,2'-Azino-bis(3-ethylbenzothiazoline-6-sulphonic acid) diammonium salt) radical cation assay according to the modified method of Re et al. (1999) [37]. The results were given as $\mu$ mol TEAC (Trolox Equivalent Antioxidant Capacity) in g of dry matter (d.m.) of the powder.

The content of the individual polyphenols was determined using the HPLC method described by Hallmann (2017) [38]. A weighed amount of powder $(100 \mathrm{mg})$ was put into a plastic test tube, and then $1 \mathrm{~mL}$ of methanol containing $1 \mathrm{~g} / 100 \mathrm{~mL}$ ascorbic acid was added. The solution was mixed thoroughly by vortexing, and was incubated in an ultrasonic bath $\left(15 \mathrm{~min}\right.$ at $\left.30^{\circ} \mathrm{C}\right)$. The samples were then swirled at a speed of $5000 \mathrm{rpm}$. From the test tube, $1 \mathrm{~mL}$ of extract was collected and re-swirled at a speed of $12,000 \mathrm{rpm}$. An aliquot of $500 \mu \mathrm{L}$ of extract was taken for analysis by HPLC (high-performance liquid chromatography), and the polyphenols were all determined using the same HPLC set-up. A Synergi Fusion-RP 80i column $(250 \times 4.60 \mathrm{~mm})$ was used, and elution was carried out using a gradient flow with two mobile phases: acetonitrile/deionised water at $\mathrm{pH} 3.00$. The analysis time was $36 \mathrm{~min}$, the flow rate was $1 \mathrm{~mL} \mathrm{~min}^{-1}$ and the wavelength range for detection was 250-370 nm. Polyphenols were identified based on Fluka and Sigma Aldrich external standards. A Shimadzu HPLC (USA Manufacturing Inc., USA) was used, consisting of two LC-20AD pumps, a CMB-20A system controller, an SIL-20AC autosampler, an SPD-20AV UV/VIS detector and a CTD-20AC controller. The results are expressed in $\mu \mathrm{g}$ of the total content of the polyphenols $\mathrm{g}^{-1} \mathrm{~d} . \mathrm{m}$. The assay was performed with three replicates.

The total vitamin $C$ sample content was determined following extraction of the ascorbic acid and dehydroascorbic acid, and then reduction using dithiothreitol reagent. HPLC was performed using a UV 2487 detector, and separation was carried out by an RP Symmetry C18 $5 \mu \mathrm{m} 4.6 \times 150 \mathrm{~mm}$ column at a temperature of $25^{\circ} \mathrm{C}$, while the injection volume varied between 10-30 $\mu \mathrm{L}$. The results were expressed in $\mathrm{mg}$ of vitamin $\mathrm{C} \mathrm{g}^{-1} \mathrm{~d}$.m. of powder.

The Water Holding Capacity (WHC) was determined according to the procedure of Sudha et al. (2007) [39]. The WHC was expressed as $g$ water $\mathrm{g}^{-1} \mathrm{~d}$.m. of powder. The Water Solubility Index (WSI) was measured using the method of Anderson et al. (1996) [40]. The results were expressed as g of the dissolved powder out of the $\mathrm{kg}$ of powder. The $\mathrm{pH}$ was measured using a Laboratory $\mathrm{pH}$-meter (Elmetron CP-511). Dry matter was measured by a gravimetric method according to AOAC (2000) [41] methodology. The $\mathrm{a}_{\mathrm{w}}$ value was measured using a manual AquaLab Water Activity Meter (Decagon Devices. Inc. Pullman, USA). The microstructure of the strawberry powders was investigated using a Quanta 200 XL series scanning electron microscope (FEI, Oregon, USA). 
Computer image analysis using Visual Analyzer 400 (Alpha M.O.S., Toulouse, France) was used to instrumentally assess the colour of the powders.

The tested powder samples were placed in a measuring chamber, which controlled the lighting conditions. Upper and lower lighting was used to avoid the shadow effect on the tested samples. To take pictures, a $16 \mathrm{~mm}$ diameter lens, focus $0.1 \mathrm{~m}$ by Fujifilm (Tokyo, Japan), was used. Measurements were made using the CIE $L^{*} a^{*} b^{*}$ system $\left(L^{*}-\right.$ brightness, $+a^{*}-$ red, $-a^{*}-$ green, $+b^{*}-$ yellow, $-b^{*}-$ blue) and RGB ( $R$ - red, G - green, B - blue).

The results of the colour analysis are given in graphs showing the share of individual colour shades to which the relevant codes are assigned. The codes correspond to the values of the colour parameters in both $\mathrm{L}^{*} \mathrm{a}^{*} \mathrm{~b}^{*}$ and RGB space. The article presents a graphical interpretation of the results obtained in order to illustrate the differences between individual samples, and an additional table with the codes of individual colour parameters is attached to enable quantitative obtained data.

The sensory characteristics of the drinks prepared from the powder samples were determined by their Quantitative Descriptive Profile (QDP) in accordance with the regulatory procedure described in ISO PN-EN ISO 13299:2016-05 (2016) [42]. The drinks were prepared by mixing $50 \mathrm{~g}$ of each powder and $50 \mathrm{~g}$ sugar per $\mathrm{kg}$ of water. Nine quality parameters were selected for analytical profiling of the powder drinks. The quality parameters were: strawberry flavour, taste (sweet, sour, bitter), colour, uniformity of appearance, smoothness, powder perceptibility and overall quality. The intensity of the abovementioned parameters was assessed on an unstructured 10-point scale in contractual units (c.u.). Ratings were performed at the Laboratory of Sensory Analysis, which meets all the criteria specified in the BS EN ISO 8589:2010 (2010) [43] standard.

Statistica 13.0 (Tibco Software Inc., Califonia, USA) software was used for all statistical processing. Analysis of variance (ANOVA) for dependent groups with the post hoc analysis of the NIR Fisher test at the significance level $p<0.05$ was used.

\section{Results and Discussion}

Table 1 shows the results of the physiochemical tests of the strawberry powders obtained by the freeze-dried (FD), convection drying (CD) and spray drying (SD) methods. The tested powders were characterised by their high dry matter content (d.m.) (ranging from 962.5 to $978.2 \mathrm{~g} \mathrm{~kg}^{-1}$ ) and correspondingly low water activity $\left(\mathrm{a}_{\mathrm{W}}\right)$ (ranging from 0.19 to 0.28 ). The low water activity is important for ensuring the microbiological stability of the powders during storage, provided that they are properly barrier packaged. An $\mathrm{a}_{\mathrm{w}}$ value of less than 0.6 is considered acceptable for raw products since microbiological activity, including that of osmophilic yeast, is reduced [29]. The low water content of dried fruit is important not only for microbiological consideration, but also because of the difficulty of grinding it into powder when the water content is higher (viscous texture). Similarly, as in the present work, low levels of $a_{w}$ were found in chokeberry and blackcurrant powders prepared by different methods $[33,34]$. The method by which the powders were obtained significantly influenced $(p<0.05)$ their physical properties, particularly their WSI and WHC. The SD powders showed the lowest significant $(p<0.05)$ water binding capacity, with the highest $(p<0.05)$ water solubility index of $885.4 \mathrm{~g} \mathrm{~kg}^{-1}$, indicating that these powders can be used for the products with the instant type of matrix where particle solubility is required, for example in beverages and jellies. Given the lower solubility of FD and CD powders, they will be particularly useful in the preparation of products where particle sensitivity is indicated, for example in smoothies, cocktails and yoghurt. The higher solubility $(p<0.05)$ (WSI) of FD powder as compared to CD powder could result from the difference in texture of these powders. In the investigations of Sadowska et al. (2019) [33,34] conducted on chokeberry and blackcurrant powders using the same methods as in this study, similar results were obtained with respect to WSI and WHC, taking into account the drying method used. 
Table 1. Physicochemical characteristics of organic strawberry fruit dried by different methods.

\begin{tabular}{|c|c|c|c|c|c|}
\hline $\begin{array}{l}\text { Type of } \\
\text { Drying }\end{array}$ & $\begin{array}{l}\text { Dry Mass } \\
\left(\mathrm{g} \mathrm{kg}^{-1}\right)\end{array}$ & Water Activity & $\mathrm{pH}$ & 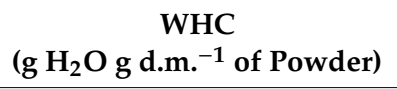 & $\begin{array}{c}\text { WSI } \\
\left(\mathrm{g} \mathrm{kg}^{-1}\right)\end{array}$ \\
\hline FD & $978.2 \pm 0.3^{c}$ & $0.10 \pm 0.001^{a}$ & $3.54 \pm 0.01$ & $2.81 \pm 0.21^{c}$ & $619.1 \pm 3.3^{b}$ \\
\hline $\mathrm{CD}$ & $962.5 \pm 3.2^{\mathrm{a}}$ & $0.27 \pm 0.002^{b}$ & $3.58 \pm 0.02$ & $2.36 \pm 0.14^{b}$ & $549.8 \pm 3.4^{\mathrm{a}}$ \\
\hline SD & $968.6 \pm 2.5^{b}$ & $0.28 \pm 0.005^{b}$ & $3.57 \pm 0.02$ & $1.05 \pm 0.11^{\mathrm{a}}$ & $885.4 \pm 4.6^{c}$ \\
\hline Raw & $915.5 \pm 5.3^{d}$ & $0.98 \pm 0.005^{c}$ & $3.56 \pm 0.02$ & - & - \\
\hline
\end{tabular}

a-d: values marked by different letters differ significantly ( $p<0.05$ ); FD: freeze drying, CD: convective drying, SD: spray drying.

Table 2 shows the content of bioactive components, such as vitamin $C$ and polyphenols, and the antioxidant activity of powders obtained from organic strawberries using the FD, CD and SD methods-the latter involving spray drying of juice on a carrier, maltodextrin. The results obtained were characterised by significantly different contents of the determined components, depending on the method of obtaining the powder. Considering the content of vitamin C, it can be concluded that both the strawberry fruit and the powders obtained from them are rich sources of this vitamin. The determined content of vitamin $C$ in organic strawberry fruit was $0.68 \mathrm{mg} \mathrm{g}^{-1}\left(8.07 \mathrm{mg} \mathrm{g}^{-1} \mathrm{~d}\right.$.m.). This value is similar to the literature data $[1,44]$.

Table 2. The content of individual polyphenols ( $\mu \mathrm{g} \mathrm{g}^{-1} \mathrm{~d} . \mathrm{m}$.), vitamin $\mathrm{C}\left(\mathrm{mg} \mathrm{g}^{-1} \mathrm{~d} . \mathrm{m}\right.$.) and antioxidant properties ( $\mu \mathrm{mol} \mathrm{TEAC} \mathrm{g}^{-1} \mathrm{~d}$.m.) of raw organic strawberry and strawberries powders obtained by different methods.

\begin{tabular}{|c|c|c|c|c|}
\hline Bioactive Compounds & Raw Strawberry & FD & CD & SD \\
\hline \multicolumn{5}{|c|}{ Phenolic acids } \\
\hline gallic acid & $691.9 \pm 2.6^{d}$ & $470.1 \pm 17.9^{c}$ & $41.5 \pm 7.3^{\mathrm{a}}$ & $71.2 \pm 0.4^{b}$ \\
\hline chlorogenic acid & $44.6 \pm 0.2^{c}$ & $41.5 \pm 2.5^{c}$ & $15.9 \pm 0.5^{\mathrm{a}}$ & $30.3 \pm 11.4^{b}$ \\
\hline caffeic acid & $175.2 \pm 22.2^{b}$ & $181.7 \pm 21.9^{b}$ & $44.3 \pm 1.2^{\mathrm{a}}$ & $46.2 \pm 3.1^{\mathrm{a}}$ \\
\hline$p$-coumaric acid & $393.8 \pm 0.4^{\mathrm{d}}$ & $357.2 \pm 7.0^{c}$ & $27.4 \pm 0.9^{a}$ & $177.7 \pm 12.5^{b}$ \\
\hline ferulic acid & $152.7 \pm 29.0^{c}$ & $115.3 \pm 4.0^{\mathrm{c}}$ & $6.0 \pm 0.5^{\mathrm{a}}$ & $69.3 \pm 6.2^{b}$ \\
\hline ellagic acid & $68.9 \pm 0.4^{c}$ & $58.5 \pm 1.7^{\mathrm{b}}$ & $64.7 \pm 4.3^{b c}$ & $32.3 \pm 1.3^{\mathrm{a}}$ \\
\hline Total phenolic acids & $1527.3 \pm 25.4^{\mathrm{d}}$ & $1224.3 \pm 3.5^{c}$ & $199.8 \pm 10.9^{a}$ & $427.1 \pm 21.1^{b}$ \\
\hline \multicolumn{5}{|c|}{ Flavonols } \\
\hline quercetin-3-O-rutinoside & $223.6 \pm 2.4^{b}$ & $179.0 \pm 43.5^{b}$ & $7.9 \pm 1.2^{\mathrm{a}}$ & $15.7 \pm 2.5^{\mathrm{a}}$ \\
\hline kaempferol-3-O-glycoside & $73.4 \pm 10.0^{\mathrm{d}}$ & $45.9 \pm 5.5^{c}$ & $30.5 \pm 2.5^{b}$ & $0.0 \pm 0.0^{\mathrm{a}}$ \\
\hline myricetin & $34.3 \pm 8.00^{c}$ & $30.5 \pm 0.1^{b}$ & $30.5 \pm 0.1^{b}$ & $11.7 \pm 1.8^{a}$ \\
\hline luteolin & $26.1 \pm 0.70^{c}$ & $23.5 \pm 0.3^{b}$ & $24.8 \pm 1.3^{b c}$ & $9.3 \pm 0.1^{\mathrm{a}}$ \\
\hline quercetin & $559.0 \pm 28.6^{\mathrm{d}}$ & $364.9 \pm 4.3^{c}$ & $309.2 \pm 6.4^{b}$ & $0.0 \pm 0.0^{\mathrm{a}}$ \\
\hline kaempferol & $37.4 \pm 0.3^{\mathrm{d}}$ & $22.6 \pm 0.4^{c}$ & $16.9 \pm 0.0^{\mathrm{a}}$ & $20.5 \pm 0.2^{b}$ \\
\hline quercetin-3-O-glycoside & $364.9 \pm 1.4^{c}$ & $274.3 \pm 9.2^{b}$ & $254.9 \pm 7.0^{\mathrm{b}}$ & $164.3 \pm 10.0^{\mathrm{a}}$ \\
\hline Total flavonols & $1318.9 \pm 27.4^{\mathrm{d}}$ & $940.7 \pm 51.7^{c}$ & $674.8 \pm 10.6^{b}$ & $221.6 \pm 10.6^{a}$ \\
\hline \multicolumn{5}{|c|}{ Anthocyanins } \\
\hline cyanidin-3,5-di-O-glycoside & $2653.7 \pm 128.1^{d}$ & $2122.1 \pm 5.5^{c}$ & $5.4 \pm 1.4^{\mathrm{a}}$ & $52.2 \pm 1.2^{b}$ \\
\hline pelargonidin-3,5-di-O-glycoside & $605.2 \pm 0.1^{\mathrm{d}}$ & $174.5 \pm 0.1^{b}$ & $63.3 \pm 1.0^{\mathrm{a}}$ & $413.8 \pm 47.4^{\mathrm{c}}$ \\
\hline pelargonidin-3,5-di-O-rutinoside & $1944.9 \pm 29.9 c$ & $2100.6 \pm 1.2 \mathrm{~d}$ & $318.1 \pm 22.9 \mathrm{~b}$ & $76.7 \pm 0.4 \mathrm{a}$ \\
\hline Total anthocyanins & $5203.8 \pm 126.2^{d}$ & $4397.2 \pm 6.6^{c}$ & $386.6 \pm 24.7^{b}$ & $542.7 \pm 11.3^{a}$ \\
\hline Total flavonoids & $6522.4 \pm 112.2^{d}$ & $5338.0 \pm 58.1^{c}$ & $1061.3 \pm 32.4^{b}$ & $764.2 \pm 53.1^{\mathrm{a}}$ \\
\hline Total sum of polyphenols & $8049.6 \pm 113.3^{c}$ & $6562.2 \pm 57.5^{b}$ & $1261.1 \pm 42.8^{a}$ & $1291.4 \pm 77.4^{\mathrm{a}}$ \\
\hline Vitamin C & $8.1 \pm 0.5^{\mathrm{d}}$ & $7.0 \pm 0.2^{c}$ & $1.55 \pm 0.04^{\mathrm{a}}$ & $3.22 \pm 0.17^{b}$ \\
\hline Antioxidant activity & $525.5 \pm 19.3^{c}$ & $370.2 \pm 8.9^{b}$ & $290.1 \pm 10.2^{\mathrm{a}}$ & $294.9 \pm 4.8^{\mathrm{a}}$ \\
\hline
\end{tabular}

a-d: values marked by different letters differ significantly ( $p<0.05)$; FD: freeze drying, CD: convective drying, SD: spray drying, d.m.: dry matter. 
Relating the obtained values to the body's needs, it was noted that the consumption of only $100 \mathrm{~g}$ of strawberries, $12 \mathrm{~g}$ of FD powder or $25 \mathrm{~g}$ of $\mathrm{CD}$ powder covers the daily needs of an adult for this vitamin [2]. The vitamin C content in FD powders was about $14 \%$ lower than in fresh fruit, while in CD powders it was about 78\% lower than in FD powders. SD powders had twice as low a content of vitamin C (3.2 $\mathrm{mg} \mathrm{g}^{-1} \mathrm{~d}$.m.) as FD; however, it should be taken into account that SD powder consisted of dried juice deprived of some solid components (i.e., stones, seeds) with an additional share of the carrier, maltodextrin, which reduces the content of this compound. The literature lacks data on vitamin $\mathrm{C}$ losses in powders obtained from strawberries using the abovementioned methods. Earlier studies by the authors on powders obtained from chokeberry and blackcurrant showed similar relationships regarding vitamin $C$ losses. In the case of blackcurrant powders obtained by the $C D$ method, vitamin $\mathrm{C}$ losses in comparison with FD powders were significantly lower than in the case of strawberries, which may have resulted from the different chemical compositions or morphological structures of these fruits $[33,34]$. The tested organic strawberries were characterised by a comparable polyphenol content to those obtained in previous studies by Hallmann et al. (2016) [45]. The studied organic strawberries and the powders obtained by the FD method were characterised by a high content of phenolic compounds, among which anthocyanins, phenolic acids and flavonols dominated. Comparing the content of phenolic compounds in powders to their content in fresh fruit, it can be seen that, in terms of dry matter content, the content of these compounds, depending on their type, decreased from $18 \%$ for FD to about $85 \%$ for SD and CD. In the FD powder the total content of phenolic compounds was several times higher than in powders obtained by the SD and CD methods. Even higher differences were observed in the case of the anthocyanin content, which indicates that the use of a long-lasting convective drying process as well as spray drying causes degradation of these compounds. Given the strawberry growing system, organic and conventional, many experiments have shown that organic fruits are richer in biologically active compounds $[7,8,46]$. Considering the above, it can be expected that the obtained content of bioactive ingredients in the tested powders may be higher than in powders that would be obtained from fruit from the conventional system. The content of phenolic compounds and vitamin $C$ determines the antioxidant activity of food. The freeze-drying process, followed by grinding the fruit into its powder form, did not significantly reduce the antioxidant properties of the fresh fruit. CD and SD powders were characterised by reduced, but still quite high, antioxidant activity. The obtained results are consistent with the results of previous studies by Sadowska et al. (2019) [33,34], in which powders obtained from chokeberry and blackcurrant were studied using the abovementioned methods, and additionally the fluidised-bed jet milling and drying method (FBJD).

Figure 1 shows the values of the sensory attributes obtained after evaluation of the powders prepared as beverages with added sugar. The beverages showed the greatest differences in the values obtained for strawberry flavour. The FD powders were characterised by the highest value of this discriminant. In the case of the texture characteristics, the greatest variation was achieved in the smoothness and uniformity of appearance. The greatest smoothness and the most uniform appearance were observed in beverages prepared from SD powders, which also showed the highest solubility values (WSI) $(p<0.05)$. 


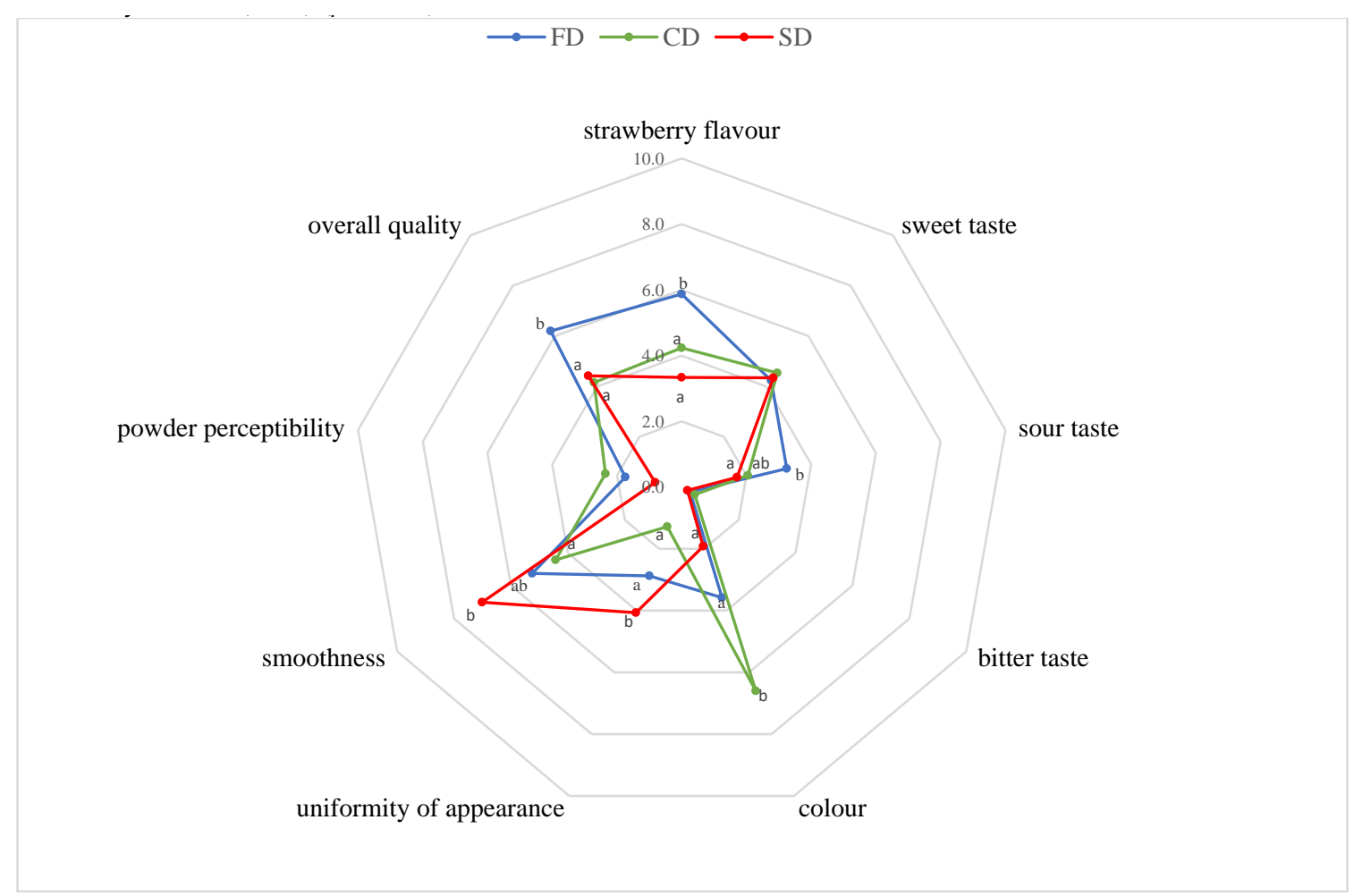

Figure 1. Sensory quality of strawberry drinks prepared with FD, CD and SD powders (a-d: values marked by different letters differ significantly ( $p<0.05)$; FD: freeze drying, CD: convective drying, SD: spray drying).

The powders studied were characterised by a large variation in colour. CD powders had a significantly different colour, i.e., reddish-brown, in comparison to SD and FD powders, which were rated as light red. A detailed colour analysis of the powders using the instrumental method ('electronic eye') is shown in Figure $2 a-c$ and in Table 3. Analysing the obtained results in the $L^{*} a^{*} b^{*}$ colour space, it can be concluded that the SD powder had a higher value of the colour parameter $L^{*}$. This means that the sample was brighter compared to the FD and CD powders. Similar relationships were obtained for the sensory colour evaluation of the powders; the colour of the SD powder was evaluated as light red and that of the FD and CD samples as dark red. The values of parameter $\mathrm{a}^{*}$ determined for the $\mathrm{SD}$ powder and the FD powder were also higher as compared to the $\mathrm{CD}$ powder, which means that the SD and FD samples had a greater colour shift towards red. There were no major differences in the colour parameter $\mathrm{b}^{*}$ for all samples tested, which means that these samples had a similar shade of yellow. Taking into account the RGB colour model, it can be seen that the SD and FD powders showed higher $\mathrm{R}$ values compared to the $\mathrm{CD}$ powder, which indicates that the SD and FD powders had a higher saturation of red colour. The value of the colour parameter B (blue) was the highest for the SD powder, which indicates that it was more saturated with blue colour. No major differences were observed for the green colour (parameter G). The results obtained in the colour of the powders evaluated by the instrumental method and the subjective sensory evaluation show a large difference in the colour of the powders obtained by different methods. Long-lasting drying of fruit by the CD method at $70{ }^{\circ} \mathrm{C}$ caused large changes in the content of anthocyanins, providing a characteristic colour change for strawberries (light red) towards dark red (brown). The resulting differences in the colour of the powders depending on the method of preparation should be taken into account in their selection as natural food colouring additives. The CD powders were characterised by a different dark red/brown colour, as opposed to the FD and SD powders, which were light red. 


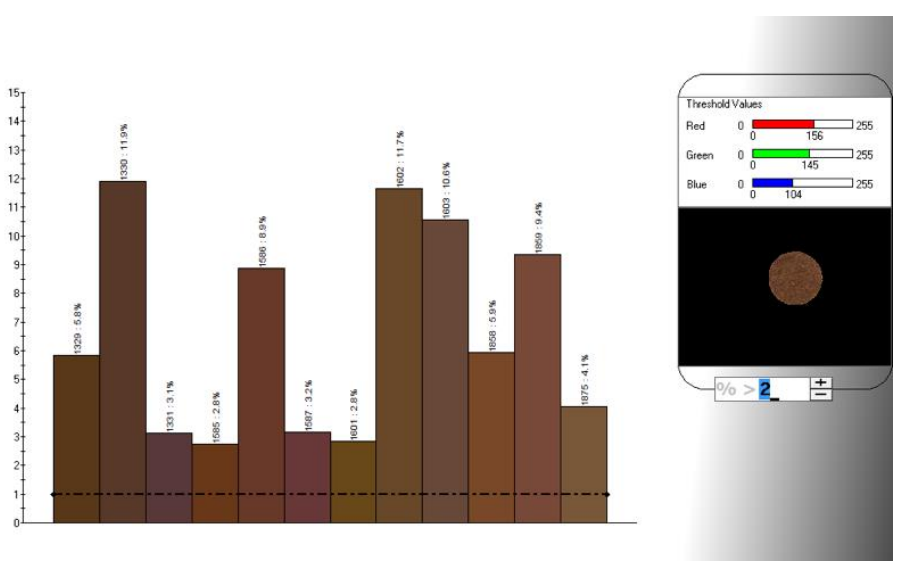

(a)
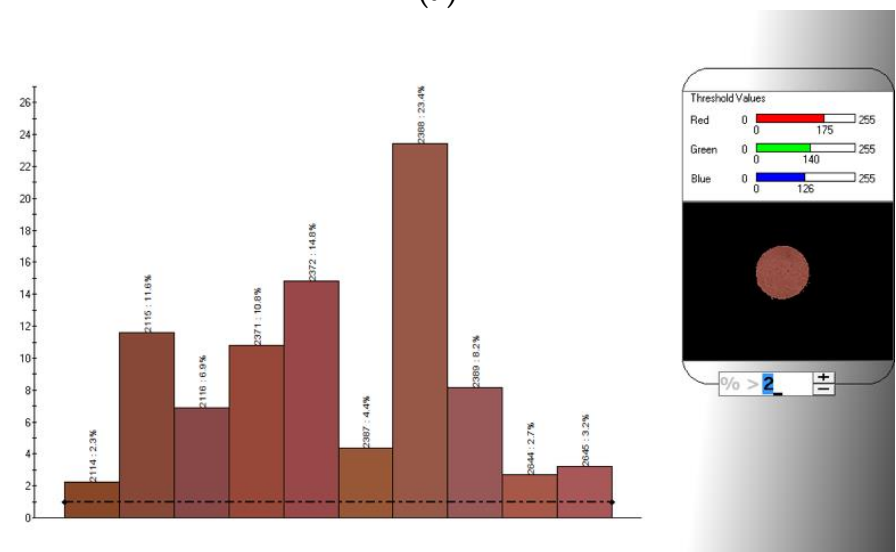

(b)
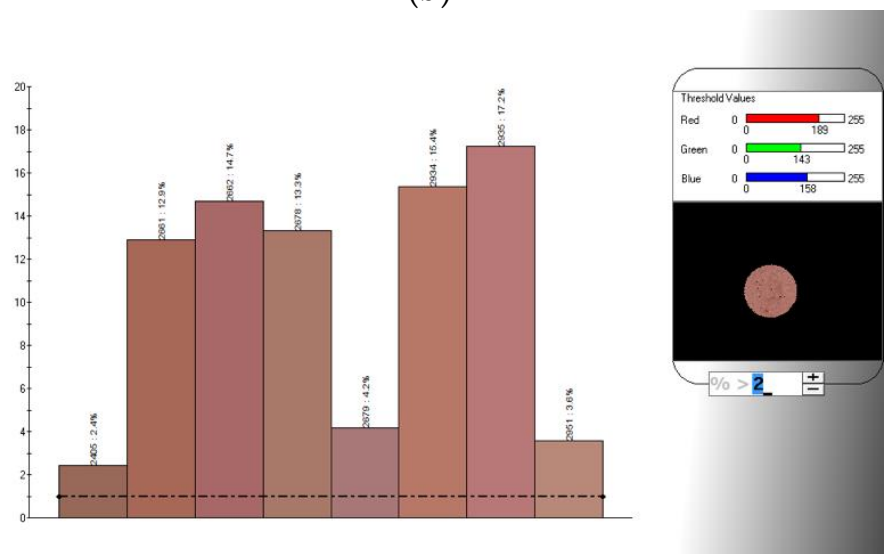

(c)

Figure 2. Graphical interpretation of strawberry powders colour distribution using the instrumental method ('electronic eye'). (a) CD powder; (b) FD powder; (c) SD powder. 
Table 3. Colour parameters in $L^{*} a^{*} b^{*}$ and RGB space obtained for organic strawberry powders prepared by various methods (FD: freeze drying, CD: convective drying, SD: spray drying).

\begin{tabular}{|c|c|c|c|c|c|c|}
\hline \multirow{2}{*}{ Colour Code } & \multicolumn{6}{|c|}{ CD } \\
\hline & $\mathrm{L}$ & a & $\mathbf{b}$ & $\mathbf{R}$ & G & B \\
\hline 1329 & 26.910 & 12.172 & 25.544 & 88 & 56 & 24 \\
\hline 1330 & 27.116 & 13.189 & 16.120 & 88 & 56 & 40 \\
\hline 1331 & 27.425 & 14.678 & 6.172 & 88 & 56 & 56 \\
\hline 1585 & 29.338 & 19.801 & 28.959 & 104 & 56 & 24 \\
\hline 1586 & 29.523 & 20.606 & 19.732 & 104 & 56 & 40 \\
\hline 1587 & 29.800 & 21.795 & 9.880 & 104 & 56 & 56 \\
\hline 1601 & 33.523 & 10.478 & 33.098 & 104 & 72 & 24 \\
\hline 1602 & 33.678 & 11.290 & 24.684 & 104 & 72 & 40 \\
\hline 1603 & 33.911 & 12.494 & 15.346 & 104 & 72 & 56 \\
\hline 1858 & 35.894 & 18.738 & 27.913 & 120 & 72 & 40 \\
\hline 1859 & 36.108 & 19.730 & 18.692 & 120 & 72 & 56 \\
\hline 1875 & 40.270 & 10.605 & 23.892 & 120 & 88 & 56 \\
\hline \multicolumn{7}{|c|}{ FD } \\
\hline 2114 & 38.292 & 25.841 & 31.361 & 136 & 72 & 40 \\
\hline 2115 & 38.487 & 26.666 & 22.278 & 136 & 72 & 56 \\
\hline 2116 & 28.754 & 27.779 & 12.824 & 136 & 72 & 72 \\
\hline 2371 & 41.012 & 33.266 & 26.042 & 152 & 72 & 56 \\
\hline 2372 & 41.256 & 34.206 & 16.681 & 152 & 72 & 72 \\
\hline 2387 & 44.550 & 24.855 & 30.223 & 152 & 88 & 56 \\
\hline 2388 & 44.766 & 25.820 & 21.233 & 152 & 88 & 72 \\
\hline 2389 & 45.045 & 27.046 & 12.035 & 152 & 88 & 88 \\
\hline 2644 & 47.107 & 32.402 & 23.771 & 168 & 88 & 72 \\
\hline 2645 & 47.366 & 33.460 & 15.637 & 168 & 88 & 88 \\
\hline \multicolumn{7}{|c|}{ SD } \\
\hline 2405 & 48.886 & 18.346 & 17.206 & 152 & 104 & 88 \\
\hline 2661 & 50.953 & 25.064 & 20.382 & 168 & 104 & 88 \\
\hline 2662 & 51.239 & 26.376 & 11.415 & 168 & 104 & 104 \\
\hline 2678 & 55.089 & 17.797 & 16.653 & 168 & 120 & 104 \\
\hline 2679 & 55.396 & 19.353 & 7.865 & 168 & 120 & 120 \\
\hline 2934 & 57.045 & 24.390 & 19.674 & 184 & 120 & 104 \\
\hline 2935 & 57.336 & 25.770 & 10.912 & 184 & 120 & 120 \\
\hline 2951 & 61.180 & 17.318 & 16.183 & 184 & 136 & 120 \\
\hline
\end{tabular}

In order to determine whether there is a relationship between the tested properties of the powders and their microstructure, images of their surfaces were taken with a scanning electron microscope (Figure 3). In the powders obtained from FD and CD strawberries, the original, porous structure of the fruit was largely destroyed as a result of the grinding process. This had a marked impact on the physical properties, especially WHC, which was only slightly higher in FD powders than in CD ones, where large changes occurred, deforming the texture of the fruit. In the FD powders, along with the destruction of the original spongy structure, these valuable properties of water absorption were much lower. A larger number of pores and a less firm, more easily disintegrating structure could have an impact on obtaining higher WSI values compared to the CD powders. In the SD powders, water was quickly evaporated at a high temperature with a high rotary atomiser speed, which resulted in the formation of round and oval shapes with some concavities on the surface, and multiple creases and other deformations. The solubility of the SD powders was high (WSI $885.4 \mathrm{~g} \mathrm{~kg}^{-1}$ ), which was a result of both the processing method and their composition (juice with the carrier). The obtained microstructure images and their relationships to the properties of strawberry powders prepared using the studied methods are similar to the results obtained in previous studies by the authors of this 
paper, in which fruit powders of chokeberry and blackcurrant with a different, harder texture were tested $[33,34]$.

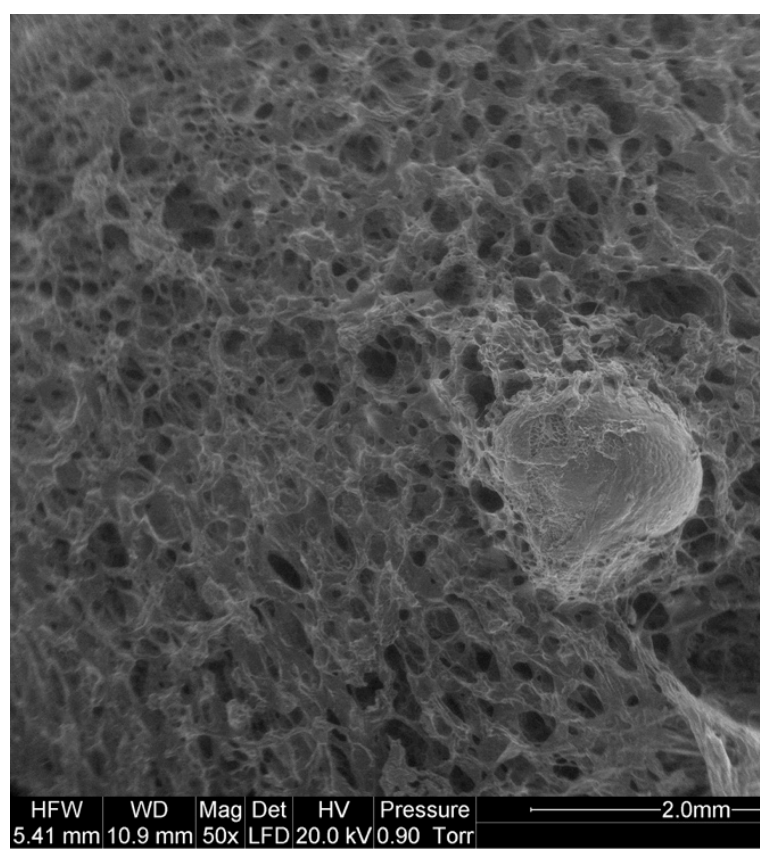

(a)

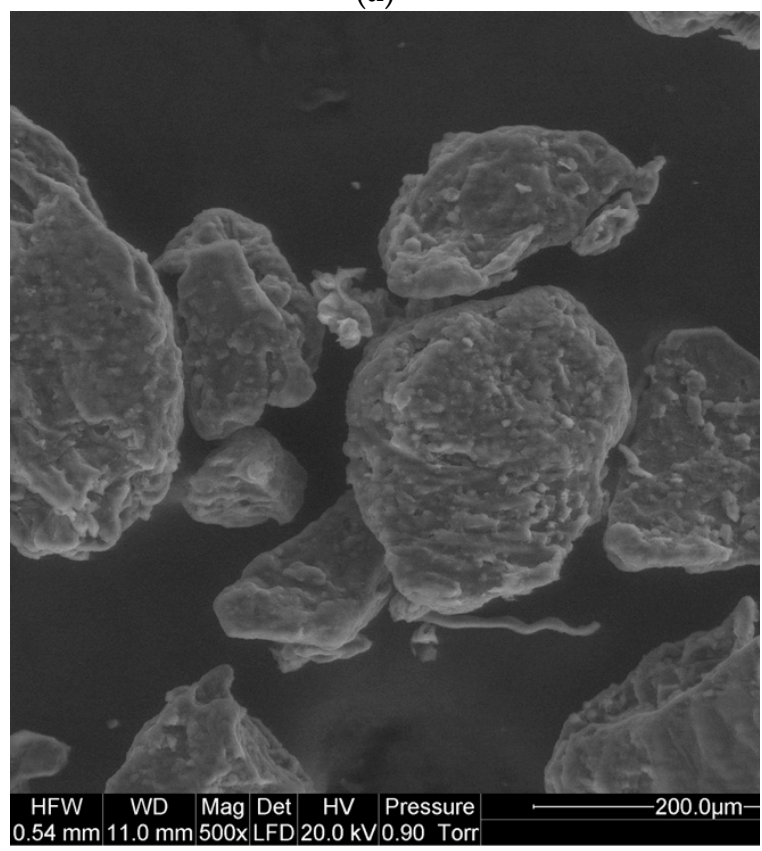

(c)

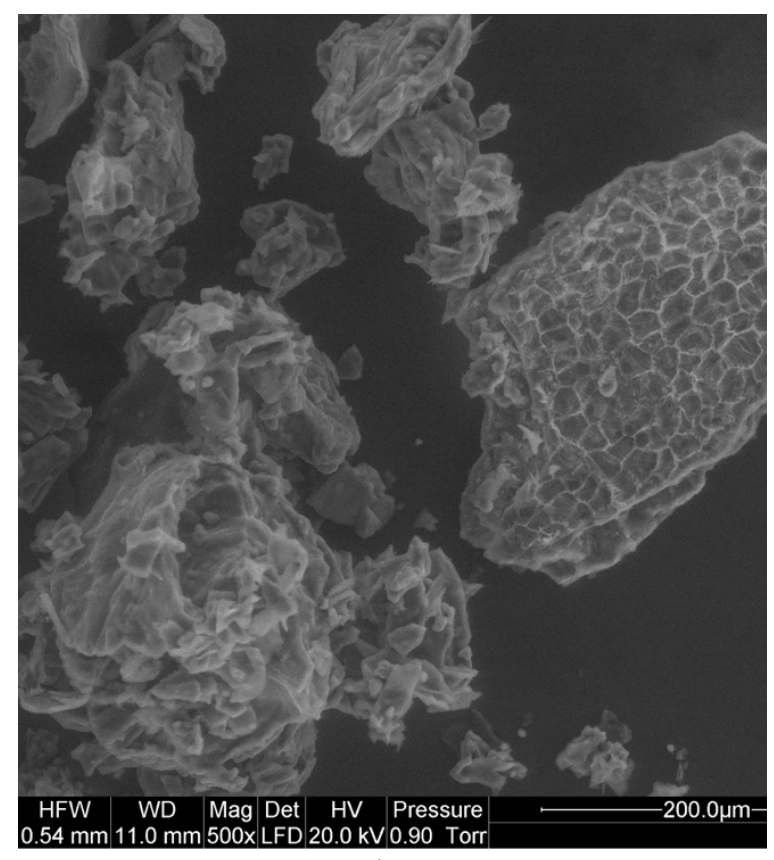

(b)

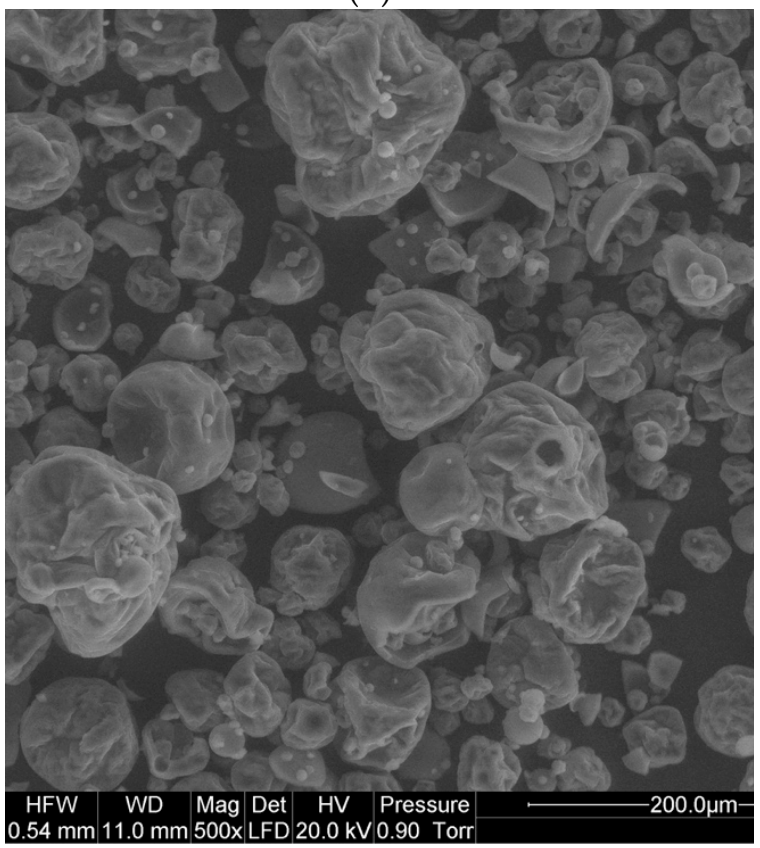

(d)

Figure 3. Microstructure of raw strawberry and strawberry powders as shown by scanning electron microscopy (magnification 50x for raw strawberry and 500x for strawberry powders); (a) raw fruit, (b) FD powder, (c) CD powder and (d) SD powder.

\section{Conclusions}

Powders obtained from organic strawberries by the most commonly used methods-FD, CD and SD-are characterised by significantly different bioactive component contents, antioxidant properties and physicochemical and sensory properties. Samples obtained from fruit that were freeze dried and then ground into powders had a high content of vitamin C, polyphenolic compounds and the highest 
antioxidant activity, similar to raw strawberries. The SD and CD powders were characterised by $60 \%$ and $80 \%$ reduced vitamin $C$ content, several times lower polyphenol content and significantly lower antioxidant properties, respectively. Powders obtained from strawberries, especially by the FD method, can be classified as 'high-value foods' due to their concentrated content of bioactive ingredients, as only $12 \mathrm{~g}$ of FD powder covers the body's daily vitamin $\mathrm{C}$ requirement, and a small addition to the food (about $5 \mathrm{~g}$ per portion) authorises it to be labelled with the nutritional statement 'high vitamin $\mathrm{C}$ content,' which means that this food contains no less than $24 \mathrm{mg}$ of vitamin C.

In the case of the CD and SD powders, their food addition should be 2-3 times higher to allow them being labelled with the abovementioned statement. The powders, depending on their method of preparation, had significantly different water binding capacity and solubility, determining their purpose. The WSI was the highest for the SD powders, which indicates that they can be used as 'instant' food components. Taking into consideration the high content of the bioactive ingredients and high operational cost of powders obtained by the FD method, these powders should be used mainly as a valuable component of high value foods and food supplements. Organic strawberry powders obtained by the CD and SD methods can also be used to enrich food with vitamin $C$ of natural origin, but this requires 2-4 times higher addition levels compared to FD powders. These powders should primarily be widely used as natural organic food additives, replacing additional substances, including those marked with the 'E' symbol, and improving sensory properties, including the taste and colour of products.

Author Contributions: Conceptualization, A.S. and F.Ś.; methodology, A.S. and E.H.; formal analysis, A.S. and E.H.; investigation, A.S. and E.H.; data curation, A.S.; writing-original draft preparation, A.S. and F.Ś.; writing—review and editing, A.S.; visualization, A.S.; supervision, F.Ś. All authors have read and agreed to the published version of the manuscript.

Funding: This research received no external funding.

Conflicts of Interest: All authors declare that they have no conflict of interest.

Human and Animal Rights Statement: This article does not contain any studies with human or animal subjects.

\section{References}

1. Viskelis, P.; Rubinskien, M.; Bobinas, C. Evaluation of strawberry and black currant berries intended for freezing and the methods of their preparation. J. Food Agric. Environ. 2008, 6, 151-154.

2. Regulation no 1169/2011 of the European Parliament and of the Council (UE) of 25 October 2011 on the Provision of Food Information to Consumers. Available online: https://eur-lex.europa.eu/legal-content/EN/ ALL/?uri=CELEX\%3A32011R1169 (accessed on 10 March 2020).

3. Seeram, N.P.; Adams, L.S.; Zhang, Y.; Lee, R.; Sand, D.; Scheuller, H.S.; Heber, D. Blackberry, Black Raspberry, Blueberry, Cranberry, Red Raspberry, and Strawberry Extracts Inhibit Growth and Stimulate Apoptosis of Human Cancer Cells In Vitro. J. Agric. Food Chem. 2006, 54, 9329-9339. [CrossRef] [PubMed]

4. Giampieri, F.; Tulipani, S.; Alvarez-Suarez, J.M.; Quiles, J.L.; Mezzetti, B.; Battino, M. The strawberry: Composition, nutritional quality, and impact on human health. Nutrition 2012, 28, 9-19. [CrossRef]

5. Forbes-Hernandez, T.Y.; Gasparrini, M.; Afrin, S.; Bompadre, S.; Mezzetti, B.; Quiles, J.L.; Giampieri, F.; Battino, M. The Healthy Effects of Strawberry Polyphenols: Which Strategy behind Antioxidant Capacity? Crit. Rev. Food Sci. Nutr. 2015, 56, S46-S59. [CrossRef] [PubMed]

6. Skrovankova, S.; Sumczynski, D.; Mlcek, J.; Jurikova, T.; Sochor, J. Bioactive Compounds and Antioxidant Activity in Different Types of Berries. Int. J. Mol. Sci. 2015, 16, 24673-24706. [CrossRef]

7. Roussos, P.; Triantafillidis, A.; Kepolas, E. Strawberry fruit production and quality under conventional, integrated and organic management. Acta Hortic. 2012, 916, 541-546. [CrossRef]

8. Conti, S.; Villari, G.; Faugno, S.; Melchionna, G.; Somma, S.; Caruso, G. Effects of organic vs. conventional farming system on yield and quality of strawberry grown as an annual or biennial crop in southern Italy. Sci. Hortic. 2014, 180, 63-71. [CrossRef]

9. Basu, A.; Nguyen, A.; Betts, N.M.; Lyons, T.J. Strawberry as a Functional Food: An Evidence-Based Review. Crit. Rev. Food Sci. Nutr. 2013, 54, 790-806. [CrossRef] [PubMed] 
10. Giampieri, F.; Alvarez-Suarez, J.M.; Battino, M. Strawberry and Human Health: Effects beyond Antioxidant Activity. J. Agric. Food Chem. 2014, 62, 3867-3876. [CrossRef]

11. Basu, A.; Morris, S.; Nguyen, A.; Betts, N.M.; Fu, D.; Lyons, T.J. Effects of Dietary Strawberry Supplementation on Antioxidant Biomarkers in Obese Adults with Above Optimal Serum Lipids. J. Nutr. Metab. 2016, 2016, 1-9. [CrossRef]

12. Henning, S.M.; Seeram, N.P.; Zhang, Y.; Li, L.; Gao, K.; Lee, R.-P.; Wang, D.C.; Zerlin, A.; Karp, H.; Thames, G.; et al. Strawberry Consumption Is Associated with Increased Antioxidant Capacity in Serum. J. Med. Food 2010, 13, 116-122. [CrossRef]

13. Casto, B.C.; Knobloch, T.J.; Galioto, R.L.; Yu, Z.; Accurso, B.T.; Warner, B.M. Chemoprevention of oral cancer by lyophilized strawberries. Anticancer Res. 2013, 33, 4757-4766.

14. Kundu, J.K.; Chun, K.-S. The Promise of Dried Fruits in Cancer Chemoprevention. Asian Pac. J. Cancer Prev. 2014, 15, 3343-3352. [CrossRef] [PubMed]

15. Chen, T.; Yan, F.; Qian, J.; Guo, M.; Zhang, H.; Tang, X.; Chen, F.; Stoner, G.D.; Wang, X. Randomized phase II trial of lyophilized strawberries in patients with dysplastic precancerous lesions of the esophagus. Cancer Prev. Res. 2011, 5, 41-50. [CrossRef]

16. Basu, A.; Fu, D.X.; Wilkinson, M.; Simmons, B.; Wu, M.; Betts, N.M.; Du, M.; Lyons, T.J. Strawberries decrease atherosclerotic markers in subjects with metabolic syndrome. Nutr. Res. 2010, 30, 462-469. [CrossRef] [PubMed]

17. Vendrame, S.; Del Bo', C.; Ciappellano, S.; Riso, P.; Klimis-Zacas, D. Berry Fruit Consumption and Metabolic Syndrome. Antioxidants 2016, 5, 34. [CrossRef]

18. Sadowska, A.; Świderski, F.; Rakowska, R.; Hallmann, E. The Functional Properties of Chokeberry and Kale Powders Obtained by an Innovative Method of Fluidised-Bed Jet Milling with Drying Compared to Freeze Drying. Int. J. Food Eng. 2017, 13. [CrossRef]

19. Soysal, Y. Microwave Drying Characteristics of Parsley. Biosyst. Eng. 2004, 89, 167-173. [CrossRef]

20. Marfil, P.; Santos, E.; Telis, V.R.N. Ascorbic acid degradation kinetics in tomatoes at different drying conditions. LWT-Food Sci. Technol. 2008, 41, 1642-1647. [CrossRef]

21. Chua, K.J.; Mujumdar, A.S.; Hawlader, M.N.A.; Chou, S.; Ho, J.C. Convective Drying of Agricultural Products. Effect of Continuous and Stepwise Change in Drying Air Temperature. Dry. Technol. 2001, 19, 1949-1960. [CrossRef]

22. Mayor, L.; Sereno, A. Modelling shrinkage during convective drying of food materials: A review. J. Food Eng. 2004, 61, 373-386. [CrossRef]

23. Ratti, C. Hot air anf freeze-drying of high-value foods: A review. J. Food Eng. 2001, 49, 311-319. [CrossRef]

24. Huang, L.-L.; Zhang, M.; Yan, W.-Q.; Mujumdar, A.S.; Sun, D.-F. Effect of coating on post-drying of freeze-dried strawberry pieces. J. Food Eng. 2009, 92, 107-111. [CrossRef]

25. Nireesha, G.R.; Divya, L.; Sowmya, C.; Venkateshan, N.; Niranjan Babu, M.; Lavakumar, V. Lyophilization: Freeze drying-an review. Int. J. Nov. Trends Pharm. Sci. 2013, 4, 87-98.

26. Karam, M.C.; Petit, J.; Zimmer, D.; Djantou, E.B.; Scher, J. Effects of drying and grinding in production of fruit and vegetable powders: A review. J. Food Eng. 2016, 188, 32-49. [CrossRef]

27. Liapis, A.I.; Bruttini, R. Freez Drying. In Handbook of Industrial Drying, 4th ed.; Mujumdar, A.S., Ed.; CRC Press: Boca Raton, FL, USA, 2014; pp. 259-282.

28. Mahn, A. Effect of Freeze-Drying Conditions on Antioxidant Compounds of Broccoli. J. Food Process. Technol. 2014, 5, 360. [CrossRef]

29. Samoticha, J.; Wojdylo, A.; Lech, K. The influence of different the drying methods on chemical composition and antioxidant activity in chokeberries. LWT-Food Sci. Technol. 2016, 66, 484-489. [CrossRef]

30. Que, F.; Mao, L.; Fang, X.; Wu, T. Comparison of hot air-drying and freeze-drying on the physicochemical properties and antioxidant activities of pumpkin (Cucurbita moschata Duch.) flours. Int. J. Food Sci. Technol. 2008, 43, 1195-1201. [CrossRef]

31. Wojdylo, A.; Figiel, A.; Oszmiański, J. Effect of Drying Methods with the Application of Vacuum Microwaves on the Bioactive Compounds, Color, and Antioxidant Activity of Strawberry Fruits. J. Agric. Food Chem. 2009, 57, 1337-1343. [CrossRef]

32. Wojdylo, A.; Figiel, A.; Lech, K.; Nowicka, P.; Oszmiański, J. Effect of Convective and Vacuum-Microwave Drying on the Bioactive Compounds, Color, and Antioxidant Capacity of Sour Cherries. Food Bioprocess Technol. 2013, 7, 829-841. [CrossRef] 
33. Sadowska, A.; Świderski, F.; Rakowska, R.; Hallmann, E. Comparison of quality and microstructure of chokeberry powders prepared by different drying methods, including innovative fluidised bed jet milling and drying. Food Sci. Biotechnol. 2019, 28, 1073-1081. [CrossRef]

34. Sadowska, A.; Rakowska, R.; Świderski, F.; Kulik, K.; Hallmann, E. Properties and microstructure of blackcurrant powders prepared using a new method of fluidized-bed jet milling and drying versus other drying methods. Cyta-J. Food 2019, 17, 439-446. [CrossRef]

35. Andrzejewska, J.; Sadowska, K.; Klóska, Ł.; Rogowski, L. The effect of plant age and harvest time on the content of chosen components and antioxidative potential of black chokeberry fruit. Acta Sci. Pol. Hortorum Cultus 2015, 14, 105-114.

36. Kazimierczak, R.; Hallmann, E.; Rusaczonek, A.; Rembiałkowska, E. Antioxidant content in black currants from organic and conventional cultivation. Electron. J. Pol. Agric. Univ. 2008, 11, 28. Available online: http://www.ejpau.media.pl/volume11/issue2/art-28.html (accessed on 2 July 2020).

37. Re, R.; Pellegrini, N.; Proteggente, A.; Pannala, A.; Yang, M.; Rice-Evans, C. Antioxidant activity applying an improved ABTS radical cation decolorization assay. Free Radic. Boil. Med. 1999, 26, 1231-1237. [CrossRef]

38. Hallmann, E.; Kazimierczak, R.; Marszałek, K.; Drela, N.; Kiernozek, E.; Toomik, P.; Matt, D.; Luik, A.; Rembiałkowska, E. The Nutritive Value of Organic and Conventional White Cabbage (Brassica OleraceaL. Var.Capitata) and Anti-Apoptotic Activity in Gastric Adenocarcinoma Cells of Sauerkraut Juice Produced Therof. J. Agric. Food Chem. 2017, 65, 8171-8183. [CrossRef]

39. Sudha, M.L.; Baskaran, V.; Leelavathi, K. Apple pomace as a source of dietary fiber and polyphenols and its effect on the rheological characteristics and cake making. Food Chem. 2007, 104, 686-692. [CrossRef]

40. Anderson, R.A.; Conway, H.F.; Pfeifer, V.F.; Griffin, E.L. Gelatinization of corn grits by roll- and extrusion-cooking. Cereal Sci. Today 1969, 14, 372-376.

41. AOAC. International Official Methods of Analysis, 18th ed.; Latimer, G.W., Jr., Ed.; AOAC International: Rockville, MD, USA, 2000.

42. ISO PN-EN ISO 13299:2016-05. Sensory Analysis-Methodology-General Guidelines for Determining the Sensory Profile. Available online: https://www.iso.org/standard/58042.html (accessed on 3 February 2020).

43. BS EN ISO 8589:2010. Sensory Analysis. General Guidance for the Design of Test Rooms. Available online: https://www.iso.org/obp/ui/\#iso:std:iso:8589:ed-2:v1:en (accessed on 3 February 2020).

44. Pavlovska, G.; Dukovska, E.; Knights, V.A.; Jankuloska, V. Influence of temperature and time of storage on amount of vitamin c in strawberries. J. Hyg. Eng. Des. 2014, 11, 15-19.

45. Hallmann, E.; Piotrowska, A.; Świąder, K. The effect of organic practices on the bioactive compounds content in strawberry fruits. J. Res. Appl. Agric. Eng. 2016, 61, 17-179.

46. Aninowski, M.; Kazimierczak, R.; Hallmann, E.; Rachtan-Janicka, J.; Fijoł-Adach, E.; Feledyn-Szewczyk, B.; Majak, I.; Leszczyńska, J. Evaluation of the Potential Allergenicity of Strawberries in Response to Different Farming Practices. Metabolism 2020, 10, 102. [CrossRef] 